\title{
Influence of environmental variables on the shrub and tree species distribution in two Semideciduous Forest sites in Viçosa, Minas Gerais, Brazil
}

\author{
Sheila Isabel do C. Pinto ${ }^{1}$, Sebastião V. Martins ${ }^{1}$, Nairam F. de Barros ${ }^{2}$, Herly Carlos T. Dias ${ }^{1}$ \& \\ Sustanis H. Kunz ${ }^{1}$ \\ 1. Departamento de Engenharia Florestal, Universidade Federal de Viçosa, 36570-000 Viçosa, MG, Brazil; \\ venancio@ufv.br \\ 2. Departamento de Solos, Universidade Federal de Viçosa, Viçosa, MG, Brazil; nfbarros@ufv.br
}

Received 29-VI-2007. C Corrected 28-II-2008. Accepted 31-VII-2008.

\begin{abstract}
The floristic variations of shrub and tree components were studied in two sites of Semideciduous Forest, initial forest and mature forest, located in the Mata do Paraíso Forest Reserve, in Viçosa, State of Minas Gerais, Southeastern Brazil, in order to analyze the floristic similarity and the correlations between environmental variables and the distribution of tree species in these forests. Individual trees with a diameter at breast height $(\mathrm{DBH}) \geq 4.8 \mathrm{~cm}$ were sampled in twenty $10 \times 30 \mathrm{~m}$ plots (10 plots in each site). The plots were distributed systematically at $10 \mathrm{~m}$ intervals. The environmental variables analyzed were: the canopy openness and soil chemical and texture characteristics. The two forest sites showed clear differences in the levels of canopy openness and soil fertility, factors that reflect the floristic and successional differences of the shrub and tree component, revealed by the low similarity between these forests by cluster analysis. The canonical correspondence analysis (CCA) of environmental variables and species abundance indicated that the species in these forests studied are distributed under strong influence of canopy openness, moisture and soil fertility. Rev. Biol. Trop. 56 (3): $1557-$ 1569. Epub 2008 September 30.
\end{abstract}

Key words: Semideciduous forest, canonical correspondence analysis, soil-vegetation relationship, hemispherical photographs, Brazil.

The fragmentation process of the Atlantic Rain Forest has become accentuated in the last decades. This forest originally occupied $12 \%$ of the Brazilian territory. Currently it is reduced to only $5 \%$ of the territory, in the form of small fragments of varied sizes, shapes, degrees of isolation, neighborhood types and disturbance history. All these hinder conservation of its biological diversity (Viana and Tabanez 1996, SOS Mata Atlântica 1998).

The situation of the native vegetation of the Minas Gerais, part of the Atlantic Rain Forest, is similar to the situation to this biome. The drastic reduction of the plant cover was caused by expansion of the agricultural frontier, and formation of pasture land and urban aglomera- tions. The originally predominant forest formation, the Semideciduous Forest, was severely modified by the coffee cycle, extensive livestock raising, and more recently, by sugarcane production. Thus the regional landscape is currently characterized as extremely fragmented, with Semideciduous Forest remnants at various stages of conservation. In this scenario, the presence of degraded and abandoned pasture is common, some of which are in the process of secondary succession (Silva Júnior et al. 2004).

The forest fragmentation today constitutes one of the greatest challenges for conservation as a result of human pressure exercised in various ways (Rodrigues et al. 2000). The 
conservation of the last forest remnants and forest restoration in degraded areas depend on the knowledge of the composition and organization of the vegetation that still exists and its relationship with environmental factors.

The floristic composition of the Brazilian forest formations and their spatial heterogeneity have been related to climatic and altitude variations, within a regional escale (Oliveira Filho and Fontes 2000, Schudeller et al. 2001). At local level, topographic, edaphic and light variation also play important roles in the spatial organization of the shrub and tree vegetation, as reported in some studies (Torres et al. 1977, Rodrigues et al. 1989, Lieberman et al. 1995, Salis et al. 1995, Clark 2002, Martins et al. 2003).

This floristic heterogeneity associated to spatial environmental variations in the tropical forests constitutes an important factor that promotes the coexistence of tree species with different ecological requirements, enabling the high floristic diversity in these forests.

The present study was carried out in two Semideciduous Forest sites, at different successional stages, in the Mata do Paraíso Forest Reserve, Viçosa, Minas Gerais State, Southeastern Brazil, to ascertain the floristic similarity between the two forest sites and possible correlations among the shrub and tree distributions as well as the environmental variables related to soil and canopy.

\section{MATERIALS AND METHODS}

Study area description: The study was carried out in the Minas Gerais Atlantic Rain Forest region $\left(20^{\circ} 48^{\prime} 07^{\prime} \mathrm{S}, 42^{\circ} 51^{\prime} 31^{\prime \prime} \mathrm{W}\right)$ belonging to the Federal University of Viçosa, $\mathrm{MG}$, area 195 hectares and altitude 690 to $800 \mathrm{~m}$, in the municipality of Viçosa, MG, Southeastern Brazil (Braz et al. 2002).

The climate in the region is of the Cwb type (Köppen) mesothermic with hot, rainy summers and cold, dry winters. The mean annual temperature is $21.8^{\circ} \mathrm{C}$ and the mean annual rainfall is $1314.2 \mathrm{~mm}$ (Castro et al. 1983). The vegetation in the reserve consists of areas of Semideciduous Forest sites (Veloso et al. 1991).

The sites chosen for the study have different disturbance and regeneration histories and were characterized by Silva Júnior et al. (2004). In one of the sites, called initial forest in this study, a process of forest regeneration has been detected in Melinis minutiflora pastures since 1963. The other forest site, called mature forest, has suffered from selective wood exploitation, forming a nucleus of well preserved forest, free from human actions in the last 40 years (Silva Júnior et al. 2004).

Currently, after more than 40 years of conservation, the Mata do Paraíso Forest Reserve presents an advanced process of regeneration forming one of the few areas with a substantial extension of preserved native forest in the region.

Vegetation survey: For the floristic and structural survey of the shrub and tree community, ten $10 \times 30 \mathrm{~m}$ plots were allocated systematically, with $10 \mathrm{~m}$ between plot spacing, in each forest site, totaling a 0.6 ha sample area. All the individuals with diameter $\geq 4.8 \mathrm{~cm}$ at $1.30 \mathrm{~m}$ from the soil (DAP) were sampled, and the perimeter was measured at $1.30 \mathrm{~m}$ above soil level (PAP). The height of the shrubs and trees in the plots was also estimated.

Botanical material was collected between January and May 2005. Identifications were made by consultations in the VIC Herbarium of the Plant Biology Department at the Federal University of Viçosa. The species were classified in families according to the Angiosperm Phylogeny Group II (APG II 2003) system.

Soil characterization: To characterize the initial and mature forest soil, eight simple soil samples were collected at a depth of $0-10 \mathrm{~cm}$, forming a compound sample in each $10 \times 30$ $\mathrm{m}$ plot in the forests studied which was submitted to chemical and texture analysis in the Soil Department at the Federal University of Viçosa. The following variables were obtained: $\mathrm{pH}$; $\mathrm{P}, \mathrm{K}, \mathrm{Ca}, \mathrm{Mg}$ and $\mathrm{Al}$ contents, saturation by bases, organic matter (Defelipo and Ribeiro 
1981), in addition to the sand, silt and clay contents and soil moisture. The edaphic variables obtained for the initial and mature forests were compared by the student $t$ test for non-paired samples.

Canopy characterization: The initial and mature forest canopies were defined by hemispheric photographs taken in the center each plot using an $8 \mathrm{~mm}$ lens with 180 degree angle (fisheye lens) attached to a photographic camera with ASA 400 film turned towards the sky.

After developing, the photographs were digitized in a scanner and classified by the PHOTOSHOP 6.0 program and processed by the HEMIPLOT program (Steege 1993), and thus the percentage of canopy openness was estimated in each plot. The mean values of the canopy openness of the two forest sites were compared by the student $t$ test for non-paired samples.

Floristic similarity between the two forest sites: FITOPAC program (Shepherd 1996) was used to analyze the floristic similarity among the plots set up in the two forest sites. A Jaccard Similairty Matrix (Mueller Dombois and Ellenberg 1974) was elaborated based on the presence or absence of species in the plots. Cluster analysis by the average linkage method (UPGMA) was used to interpret floristic similarity between the two forest sites.

Canonical correspondence analyses: The correlations between the environment and vegetation were analyzed by the canonical correspondence (CCA) (ter Braak 1987) using the PC-ORD program for Windows numeral 4.14 version (Mccune and Mefford 1999). The species abundance matrix was formed from the number of individuals per plot of the species that presented five or more individuals in the total sample, in a total of 43 species used in canonical correspondence analysis. According to the recommendations by ter Braak (1995), the abundance values (a) were transformed by the expression $\ln (\mathrm{a}+1)$ to compensate the deviations caused by a few very high values.
The environmental variable matrix included, in principle, all the soil chemical and texture variables, in addition to the percentage of canopy openness and soil moisture. Eleven environmental variables were eliminated after performing a preliminary CCA that were weakly correlated or highly redundant with other variables. The final CCA was processed with the eight most representative variables that were most strongly correlated with the classification axles: canopy openness percentage, sand, silt and soil moisture, $\mathrm{pH}$, sum of the bases, saturation by aluminum and organic matter.

\section{RESULTS}

Soil characterization: Table 1 shows the soil characteristics (superficial 0-10 cm layer) of the initial and mature forests and the main differences in the soil chemical and texture properties.

The soils of the initial and mature forests were different in texture, presenting significant differences in sand and silt contents. The soil in the initial forest presented a larger percentage of sand (38.7\%) while the mature forest soil presented a larger percentage of silt $(21.4 \%)$ in addition to greater moisture.

The soil of the mature forest presented greater macro nutrient contents ( $\mathrm{P}, \mathrm{K}, \mathrm{CA}$ and $\mathrm{Mg}$ ) and lower aluminum contents compared to the soil of the initial forest that resulted in higher values of the sum of the bases (SB), saturation by bases $(\mathrm{V})$, in addition to higher $\mathrm{pH}$ and greater organic matter content (MO).

Canopy characterization: The canopy openness ranged from $2.74 \%$ to $7.76 \%$ in the plots in the initial forest, presenting on average $5.85 \%$ canopy openness in this forest. The canopy openness ranged from $2.51 \%$ to $5.97 \%$ in the mature forest plots and the mean canopy openness of the forest was $3.69 \%$. There were significant differences in the analysis of the canopy openness in the plots studied between the initial and mature forest $(\mathrm{p}<0.01)$ (Table 2$)$. 
TABLE 1

Chemical and textural variables in 20 superficial soil samples $(0-10 \mathrm{~cm}$ layer) collected in initial and mature forests in the Mata do Paraíso Forest Reserve in Viçosa, MG, Brazil

Initial forest

Mean \pm standard deviations

$\mathrm{pH}$ at $\mathrm{H}_{2} \mathrm{O}$

$\mathrm{P}\left(\mathrm{mg} \mathrm{dm}^{-3}\right)$

$\mathrm{K}\left(\mathrm{mg} \mathrm{dm}^{-3}\right)$

$\mathrm{Ca}\left(\mathrm{cmol}_{\mathrm{c}} \mathrm{dm}^{-3}\right)$

$\mathrm{Mg}\left(\mathrm{cmol}_{\mathrm{c}} \mathrm{dm}^{-3}\right)$

$\mathrm{Al}\left(\mathrm{cmol}_{\mathrm{c}} \mathrm{dm}^{-3}\right)$

$\mathrm{H}+\mathrm{Al}\left(\mathrm{cmol}_{\mathrm{c}} \mathrm{dm}^{-3}\right)$

$\mathrm{SB}\left(\mathrm{cmol}_{\mathrm{c}} \mathrm{dm}^{-3}\right)$

$\mathrm{t}\left(\mathrm{cmol}_{\mathrm{c}} \mathrm{dm}^{-3}\right)$

$\mathrm{T}\left(\mathrm{cmol}_{\mathrm{c}} \mathrm{dm}^{-3}\right)$

$\mathrm{V}(\%)$

m (\%)

MO (dag kg-1)

Sand (\%)

Clay (\%)

Silt $(\%)$

Moisture (\%)

$$
\begin{gathered}
4.47 \pm 0.09 \\
1.43 \pm 0.45 \\
38.70 \pm 3.02 \\
0.814 \pm 0.31 \\
0.43 \pm 0.16 \\
1.18 \pm 0.34 \\
9.11 \pm 0.95 \\
1.34 \pm 0.42 \\
2.52 \pm 0.33 \\
10.45 \pm 0.87 \\
12.89 \pm 4.12 \\
47.13 \pm 12.40 \\
5.62 \pm 0.42 \\
38.70 \pm 3.23 \\
50.30 \pm 5.12 \\
11.00 \pm 5.03 \\
27.11 \pm 1.63
\end{gathered}
$$

Mature forest

$P^{\text {a }}$

Mean \pm standard deviations

$\begin{array}{rlr}5.38 & \pm 0.56 & 0.000^{* *} \\ 2.55 & \pm 0.94 & 0.003^{* *} \\ 66.70 & \pm 19.76 & 0.000^{* *} \\ 5.27 & \pm 1.78 & 0.000^{* *} \\ 1.45 \pm 0.49 & 0.000^{* *} \\ 0.17 \pm 0.23 & 0.000^{* *} \\ 4.96 \pm 1.85 & 0.000^{* *} \\ 6.89 \pm 2.26 & 0.000^{* *} \\ 7.06 \pm 2.07 & 0.000^{* *} \\ 11.85 & \pm 0.99 & 0.003^{* *} \\ 57.66 \pm 16.45 & 0.000^{* *} \\ 3.52 \pm 4.95 & 0.000^{* *} \\ 7.04 \pm 1.07 & 0.001^{* *} \\ 23.50 \pm 13.77 & 0.003^{* *} \\ 55.10 \pm 11.32 & 0.237^{\mathrm{NS}} \\ 21.40 \pm 3.69 & 0.000^{* *} \\ 48.77 \pm 8.94 & 0.000^{* *}\end{array}$

${ }^{a}$ Comparisons were made by the non-paired t test $(n=10)$, where: $\left(* *\right.$ significance at the level of $1 \%$ probability; ${ }^{\mathrm{NS}}$ absence of significance). SB (sum of exchangeable bases); $\mathrm{t}$ (effective cationic exchange capacity); $\mathrm{T}$ (cationic exchange capacity at pH 7.0); V (saturation by bases index); m (saturation index by aluminum); MO (organic matter).

TABLE 2

Canopy openness values determined by hemispheric photographs in the plots in the initial and mature forests in the Mata do Paraíso Forest Reserve in Viçosa, MG, Brazil

Initial forest

$\begin{array}{cc}\text { Plots } & \text { Canopy openness (\%) } \\ 1 & 5.32 \\ 2 & 6.12 \\ 3 & 6.40 \\ 4 & 7.61 \\ 5 & 7.25 \\ 6 & 2.74 \\ 7 & 3.44 \\ 8 & 7.76 \\ 9 & 6.17 \\ 10 & 5.65 \\ \text { deviations } & 5.846 \pm 1.666^{*}\end{array}$

* Comparisons were made by the non-paired t test $(\mathrm{P}<0.01)$
Mature forest

Canopy openness $(\%)$
4.32
3.24
4.03
4.38
3.32
5.97
2.88
2.93
3.37
2.51
$3.695 \pm 1.014 *$


Floristic similarity between the two forest sites: Fig. 1 shows floristic relationships visualized by the dendrogram generated by the average linkage method (UPGMA), based on the Jaccard Similairty Matrix. The dendrogram shows graphically that two large plot clusters were formed. There was a $70 \%$ level similarity in the first group, established for the plots located in the initial forest (from 1 to 10), while the second group, at 23\% similarity level, consisted of plots located in the mature forest (from 11 to 20).

The highest similarity indices were obtained between the plots belonging to the same forest site. Therefore the floristic composition is heterogeneous between the two sites resulting from the differences in the environmental variables studied.

Canonical correspondence analysis: The items and values of the analysis of canonical correspondence analysis (CCA) for the two first classification axes were 0.71 (axis 1) and 0.123 (axis 2), with the first axis explaining $36.0 \%$ and the second, $6.6 \%$ of the variance in the data.
The CCA produced high species environment correlations on the two first axes: 0.973 (axis 1) and 0.979 (axis 2). The Monte Carlo permutation test indicated that the species abundance and environmental variables correlated significantly with the first and second classification axes $(p=0.01)$. The variables that were most highly correlated with the first axes were, in decreasing order, saturation by aluminum, sum of the bases and soil moisture (Table 3).

The plot classification on the first axis (Fig. 2) showed clear differentiation for the edaphic and canopy openness characteristics from left to right, involving increased soil fertility, the silt fraction, $\mathrm{pH}$, organic matter content, moisture and reduction in the aluminum content and canopy openness.

\section{DISCUSSION}

Soil characterization: The soil in the mature forest was eutrophic, with good saturation by bases (V), good effective cationic exchange capacity $(t)$, and low aluminum values. The soil in the initial forest was distrophic, with very low saturation by bases (V), low

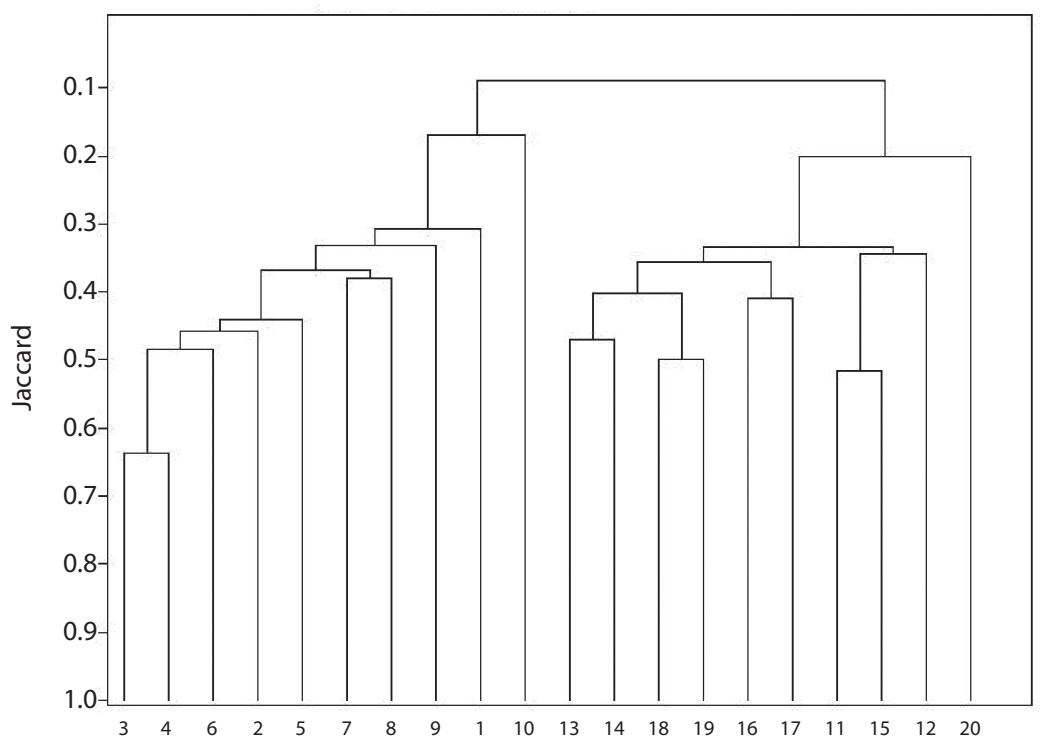

Fig. 1. Dendrogram obtained by the average linkage method (UPGMA) based on the Jaccard Similairty Matrix, for the presence and absence data of the species in the initial (plots 1 to 10) and mature forest (plots 11 to 20) in Viçosa, MG, Brazil. 
TABLE 3

Canonical correspondence analysis (CCA): Canonical coefficients and internal correlations on the first two classification axes and weighted correlation matrix for the environmental variables used in the analysis. Correlations with absolute values superior to 0.5 are indicated in bold ${ }^{a}$

\begin{tabular}{|c|c|c|c|c|c|c|c|c|c|c|}
\hline \multirow{2}{*}{ IV } & \multicolumn{2}{|c|}{ Correlation } & \multirow{2}{*}{$\mathrm{CO}$} & \multirow{2}{*}{ Sand } & \multirow{2}{*}{ Silt } & \multirow{2}{*}{$\mathrm{pH}$} & \multirow{2}{*}{ SB } & \multirow{2}{*}{$\mathrm{m}$} & \multirow{2}{*}{$\mathrm{MO}$} & $M$ \\
\hline & Axis 1 & Axis 2 & & & & & & & & IVIt \\
\hline $\mathrm{AB}^{1}$ & -0.676 & 0.052 & - & & & & & & & \\
\hline Sand & -0.652 & 0.253 & 0.439 & - & & & & & & \\
\hline Silt & 0.815 & -0.010 & -0.427 & -0.721 & - & & & & & \\
\hline $\mathrm{pH}$ & 0.797 & 0.483 & -0.461 & -0.310 & 0.657 & - & & & & \\
\hline $\mathrm{SB}^{1}$ & 0.911 & 0.364 & -0.551 & -0.462 & 0.740 & 0.964 & - & & & \\
\hline $\mathrm{m}^{1}$ & -0.974 & -0.060 & 0.663 & 0.514 & -0.766 & -0.815 & -0.894 & - & & \\
\hline $\mathrm{MO}^{1}$ & 0.714 & 0.016 & -0.327 & -0.840 & 0.700 & 0.503 & 0.640 & -0.595 & - & \\
\hline $\mathrm{Mt}$ & 0.899 & -0.284 & -0.636 & -0.670 & 0.732 & 0.686 & 0.766 & -0.784 & 0.599 & - \\
\hline
\end{tabular}

${ }^{\text {a }} \mathrm{CO}$ (canopy openness); SB (sum of exchangeable bases); m (saturation index by aluminum); MO (organic matter); Mt: moisture.

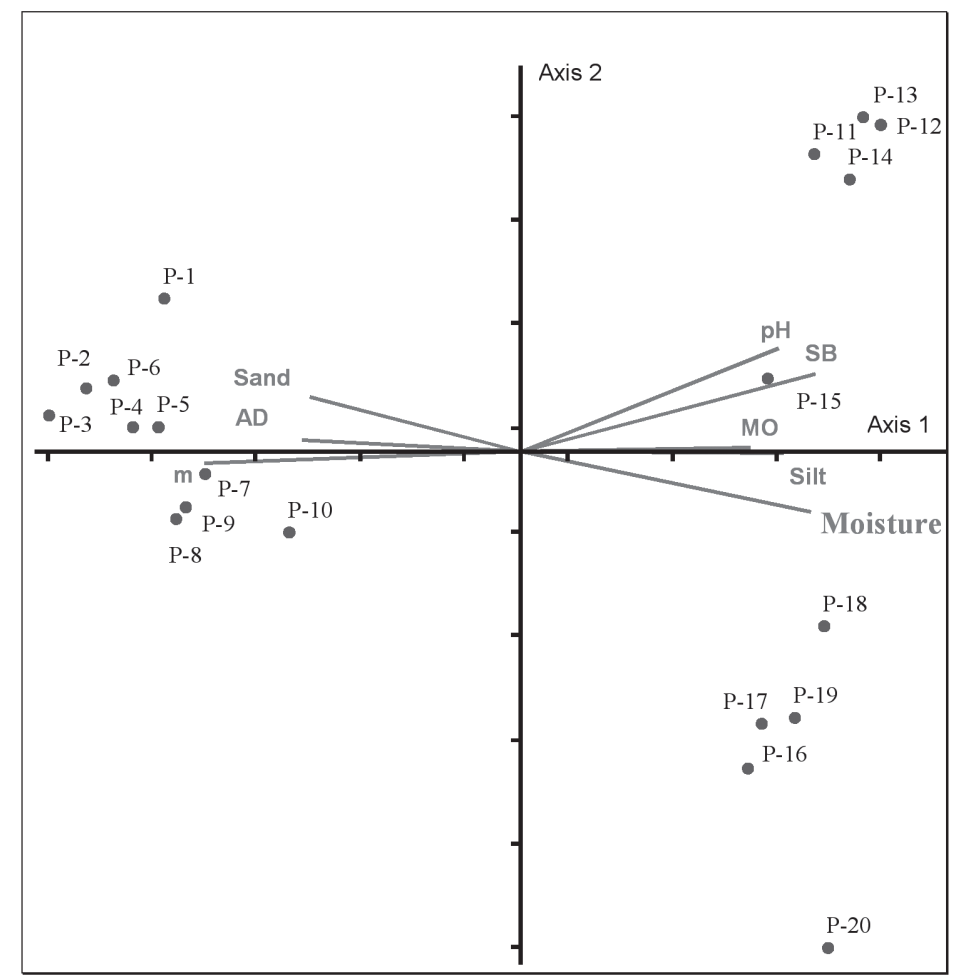

Fig. 2. Canonical correspondence analysis: ordering diagram of the plots in the initial forest (1 to 10) and mature forest (11 to 20) in the Forest Reserve Mata do Paraíso, Viçosa, MG, Brazil, based on the distribution of 43 shrub-tree species in 20 plots. The plots are represented by the corresponding numeration and the environmental variables by vectors (SB - sum of exchangeable bases; $\mathrm{m}$ - saturation index by aluminum; MO - organic matter; AD - canopy oppenness). 
effective cationic exchange capacity $(\mathrm{t})$ and high acidity (Alvarez et al. 1999). These differences in soil fertility in the two forest sites must be associated to the historic of soil use. The low fertility in the initial forest soil may be the result of its intensive use in the past as pasture. The techniques normally used in pasture renovation, such as burning plant remains, result in nutrient exportation and losses, mainly by volatilization and lixiviation (Kauffman et al. 1998, Ellingson et al. 2000).

The different edaphic characteristics presented by the initial and mature forest soils were important because they show the influence of soil quality on the succession process, accelerating this process in the more fertile environments, reaching more rapidly the stages of greater equilibrium and sustainability.

Canopy characterization: Compared to other studies that have also used hemispheric photographs, the canopy openness values in the mature forest were similar to those obtained in other well preserved tropical forests with closed canopy, while the values of the initial forest were similar to those reported in natural gaps (Brown 1993, Whitmore et al. 1993, Valverde and Silvertown 1997, Trichon et al. 1998, Martins and Rodrigues 2002).

As canopy openness is considered a good indicator of light conditions in the forest (Brown 1993, Whitmore et al. 1993, Trichon et al. 1998, Martins and Rodrigues 2002), these differences between the two forest sites must determine the division of this resource by species of the different ecological groups (Silva Júnior et al. 2004), contributing to the establishment of light requiring and shade tolerant species in the initial and mature forests, respectively.

Therefore the variations recorded for this parameter suggested a heterogeneous solar radiation penetration regimen in these environments that could thus generate different standards regarding the forest structure and ecology of the species present in these environments, forming an important source of spatial floristic heterogeneity in this forest fragment.
Floristic similarity between the two forest sites: The forest remnants can be considered floristicly similar whenever they present at least 25\% similarity (Müller Dumbois and Ellenberg 1974). Therefore, the initial and mature forests were not very similar. The heterogeneity between the two forest sites may result from variations in environmental conditions, the ecological preferences of the species and further from the diverse degrees of disturbance caused by man (Bertoni and Martins 1987).

The low floristic similarity between the initial and mature forests, with only 33 species common to the two areas, meant that all the plots in the initial forest formed a distinct group, differing from all the plots in the mature forest that formed another distinct group in the cluster analysis. These similarity groups thus established were related to the ecological conditions of these forest sites. Several different factors in association, such as disturbance history, successional stage, light quantity and quality, soil moisture and nutrient availability, influenced floristic heterogeneity between the two forest sites and accounted for the maintenance of the floristic diversity in this Semideciduous Forest.

\section{Environment and plant data classifica-} tion: The eigenvalues of the canonical correspondence analysis (CCA) for the two first axes were considered high compared with other studies on Semideciduous Forests in southeastern Brazil (Martins et al. 2003, Souza et al. 2003, Camagos 2004, Martins and Rodrigues 2005), which indicated the occurrence of species restricted to the environment of certain plots in each forest site.

Similarly to the cluster analysis, CCA also presented a clear distinction between the plots in the initial forest (1 to 10) and those in the mature forest (11 to 20), regarding the edaphic and canopy openness characteristics. The initial forest environment presented acid soil, with low fertility, and greater canopy openness that helped light penetration. The mature forest was situated on soil with greater chemical fertility 
and lower acidity, the canopy was closed and the understory very shaded.

Species classification by CCA (Fig. 3 ) indicated that Vernonanthura diffusa, Sparattosperma leucanthum, Xylopia sericea, Senna macranthera, Siparuna guianensis, Psychotria vellosiana, Piptocarpha macropoda, Miconia cinnamomifolia, Erythroxylum pelleterianum, Luehea grandiflora and Vismia guianensis were more abundant in areas with greater luminosity, sandy soils, low fertility, moisture and acid.

The distribution of this group of species corroborated their successional classification as pioneers or initial secondary individuals, associated to open environments and poor soils. Senna macranthera and Luehea grandiflora were also strongly related to better drained, acid and low nutrient soils in a study carried out in a Semideciduous forest fragment in Minas Gerais, Brazil (Souza et al. 2003).

In a cloud forest in southeastern Brazil, Psychotria vellosiana distribution presented strong correlation with greater canopy openness, which was justified by its greater light requirement because it is short and does not reach the forest canopy, and it depends on locations with more open canopy (Carvalho et al. 2000). Xylopia sericea and Miconia cinnamomifolia were more abundant on poor soils, with greater aluminum contents and more clay in another forest fragment in Viçosa, Minas Gerais, Brazil (Martins et al. 2003), and were associated with well-drained soils (Lorenzi 1992).

Siparuna guianensis is considered a generalist for habitat, and can be found in open environments with low fertility soils of the

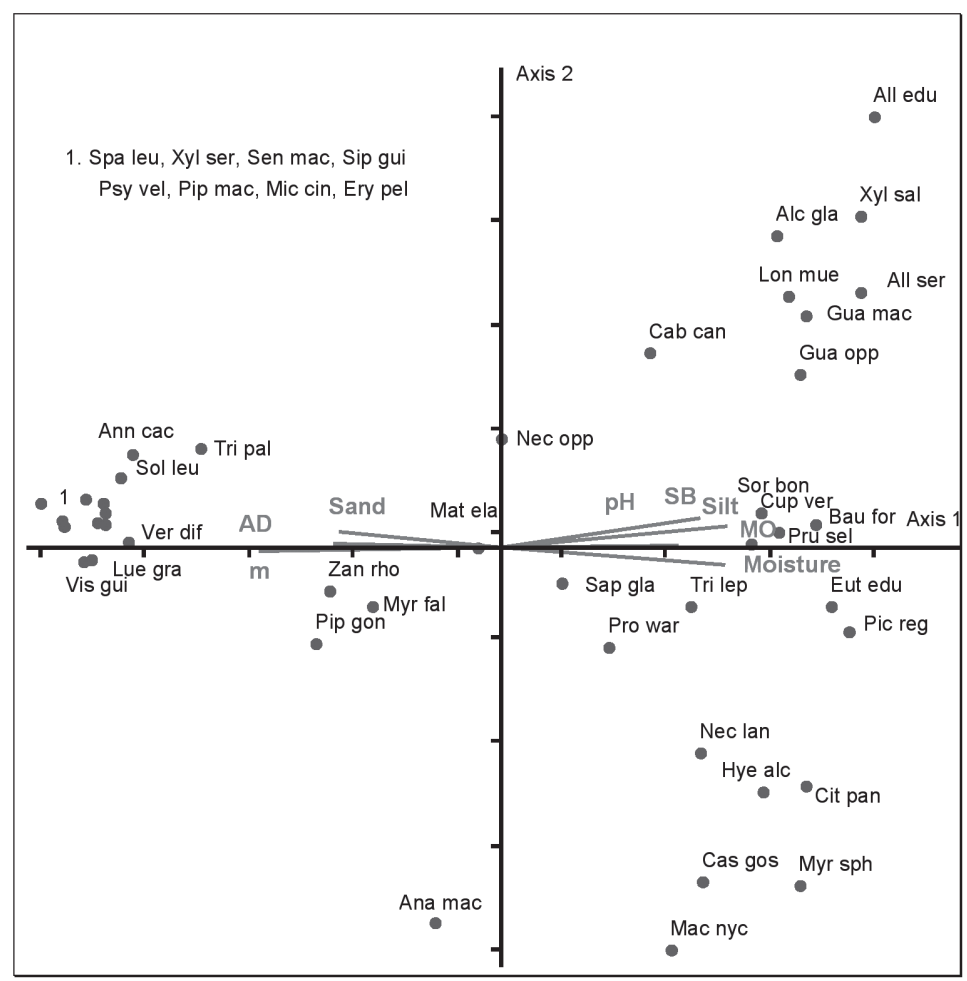

Fig. 3. Canonical correspondence analysis: ordering diagram of the species based on the distribution of shrub and tree species in 20 plots in the initial and mature forests in the Forest Reserve Mata do Paraíso, Viçosa, MG, Brazil. The species are represented by their abbreviated names (Table 4) and the environmental variables by vectors (SB - sum of exchangeable bases; $\mathrm{m}$ - saturation index by aluminum; MO - organic matter; $\mathrm{AD}$ - canopy oppenness). 
TABLE 4

Tree-shrub species sampled (number of individuals $\geq 5$ ) in the initial and mature forests in the Forest Reserve Mata do Paraíso, in Viçosa, $M G$, and respective abbreviated names

Abbreviated Names

Alc gla

All edu

All ser

Ana mac

Ann cac

Bau for

Cab can

Cas gos

Cit pan

Cup ver

Ery pel

Eut edu

Gua mac

Gua opp

Hye alc

Lon mue

Lue gra

Mac nyc

Mat ela

Mic cin

Myr fal

Myr sph

Nec lan

Nec opp

Pic reg

Pip gon

Pip mac

Pro war

Pru sel

Psy vel

Sap gla

Sen mac

Sip gui

Sol leu

Sor bon

Spa leu

Tri lep

Tri pal

Ver dif

Vis gui

Xyl sal

Xyl ser

Zan rho
Species

Alchornea glandulosa

Allophylus edulis

Allophylus sericeus

Anadenanthera macrocarpa

Annona cacans

Bauhinia forficata

Cabralea canjerana

Casearia gossypiosperma

Citronella paniculata

Cupania vernalis

Erythroxylum pelleterianum

Euterpe edulis

Guarea macrophylla

Guapira opposita

Hyeronima alchorneoides

Lonchocarpus muehlbergianus

Luehea grandiflora

Machearium nyctitans

Matayba elaeagnoides

Miconia cinnamomifolia

Myrcia fallax

Myrcia sphaerocarpa

Nectandra lanceolata

Nectandra oppositifolia

Picramnia regnelli

Piptadenia gonoacantha

Piptocarpha macropoda

Protium warmingiana

Prunus sellowii

Psychotria vellosiana

Sapium glandulatum

Senna macranthera

Siparuna guianensis

Solanum leucodendron

Sorocea bonplandii

Sparattosperma leucanthum

Trichilia lepidota

Trichilia pallida

Vernonanthura diffusa

Vismia guianensis

Xylosma salzmannii

Xylopia sericea

Zanthoxylum rhoifolium
Family

Euphorbiaceae

Sapindaceae

Sapindaceae

Fabaceae

Annonaceae

Fabaceae

Meliaceae

Salicaceae

Icacinaceae

Sapindaceae

Erythroxylaceae

Arecaceae

Meliaceae

Nyctaginaceae

Euphorbiaceae

Fabaceae

Malvaceae

Fabaceae

Sapindaceae

Melastomataceae

Myrtaceae

Myrtaceae

Lauraceae

Lauraceae

Picramnaceae

Fabaceae

Asteraceae

Burseraceae

Rosaceae

Rubiaceae

Euphorbiaceae

Fabaceae

Siparunaceae

Solanaceae

Moraceae

Bignoniaceae

Meliaceae

Meliaceae

Asteraceae

Clusiaceae

Salicaceae

Annonaceae

Rutaceae 
Cerrado (Oliveira Filho and Ratter 1995), in the Semideciduous forest understory (Martins et al. 2003), and on fragment borders with greater light incidence (Souza et al. 2003).

This group of species adapted to more selective edaphic conditions, such as high acidity, low moisture and fertility as well as greater luminosity, present potential for use in forest restoration projects in degraded areas, such as degraded pastures.

The other extreme of the environmental gradient represented by axis 1 included Sorocea bonplandii, Cupania vernalis, Prunus sellowii, Euterpe edulis, Picramnia regnelli, Citronella paniculata, Guarea macrophylla, Guapira opposita, Trichilia lepidota and Hyeronima alchorneoides, that occurred in more shady environments with more fertile soil, moisture and greater organic matter content. This plant group was characterized mainly by late secondary species that regenerated in the shade, such as Euterpe edulis, Picramnia regnelli, Guarea macrophylla and Trichilia lepidota that were found in this forest site with more closed canopy, in addition to the greater soil moisture and fertility, suitable conditions for regeneration. Picramnia regnelli is a low tree that does not naturally reach the forest canopy, and completes its reproductive cycle in the shaded understory.

The number of shade tolerant species in this forest site resulted in a negative relationship between the openness level of the canopy and light incidence on the lowest stratas that hindered regeneration of the heliophyte species of the initial successional stages (Durigan et al. 2000). Under closed canopy, late secondary species can still tolerate shade by means of low growth rates for long periods (Souza and Válio 2003).

The set of greater shading, greater soil moisture contents and greater fertility of the soil in the mature forest may favor regeneration of more demanding late species. These ecological conditions may be particularly important for E. edulis, a shade tolerant Palm that prefers soils with higher fertility and moisture (Souza and Válio 2003).
Some species in this group have been indicated and used in riparian forest restoration, including Citronella paniculata, Hyeronima alchorneoides and Euterpe edulis (Martins 2007), but all have potential for this purpose and for enriching plantations in burnt clearings and secondary forests.

The set of results attained corroborated studies that report the spatial floristic heterogeneity of Brazilian Semideciduous Forests, determined by the complexity of the relationship between environmental and distribution variables of the tree and shrub species in these forests (Pagano and Leitão Filho 1987, Rodrigues et al. 1989, Martins and Rodrigues 2002, Martins et al. 2003, 2004, Souza et al. 2003, Silva Júnior et al. 2004).

The canonical correspondence analysis (CCA) of the environmental variables and tree and shrub species abundance indicated that these were distributed in the studied forest sites, which were strongly influenced by the canopy openness, soil moisture and chemical fertility.

The initial forest environment presented acid soils, with poor fertility and greater canopy openness, helping in light penetration that favored the establishment of pioneer and initial secondary species such as Vernonanthura diffusa, Sparattosperma leucanthum, Xylopia sericea, Senna macranthera, Siparuna guianensis, Psychotria vellosiana, Piptocarpha macropoda, Miconia cinnamomifolia, Erythroxylum pelleterianum, Luehea grandiflora and Vismia guianensis.

The mature forest occurred on more fertile soils, the canopy was more closed which reduced light penetration and favored the establishment mainly of late secondary species such as Sorocea bonplandii, Prunus sellowii, Euterpe edulis, Picramnia regnelli, Citronella paniculata, Guarea macrophylla, Guapira opposita, Trichilia lepidota and Hyeronima alchorneoides.

\section{RESUMEN}

Estudiamos las variaciones florísticas de arbustos y árboles en dos sitios de un bosque semicaducifolio, bosque 
primario y bosque maduro, en la Reserva Forestal Mata do Paraíso, en Viçosa, Estado de Minas Gerais, Sudeste de Brasil, para analizar la similitud florística y las correlaciones entre las variables ambientales y la distribución de tres especies en estos bosques. Árboles individuales con diámetro a la altura del pecho (DAP) $\geq 4.8 \mathrm{~cm}$. fueron muestreados en veinte parcelas de 10 x $30 \mathrm{~m}$ (10 parcelas en cada sitio). Las parcelas se distribuyeron sistemáticamente a intervalos de $10 \mathrm{~m}$. Las variables ambientales fueron analizadas así: la abertura del dosel y características químicas y de textura del suelo. Los dos sitios de bosque mostraron diferencias evidentes en la abertura del dosel y fertilidad del suelo, factores que reflejan las diferencias florísticas y sucesionales de arbustos y árboles, revelado por la baja similitud entre estos bosques por medio de análisis de conglomerados. El análisis de correspondencia canónica (CCA) de variables ambientales y abundancia de especies indican que las especies en los bosques estudiados están distribuidas bajo una fuerte influencia de la abertura del dosel, humedad y fertilidad del suelo.

Palabras clave: bosque semicaducifolio, análisis de correspondencia canónica, relación suelo-vegetación, fotografías hemisféricas, Brasil.

\section{REFERENCES}

Alvarez, V.H., R.F. Novais, N.F. Barros, R.B. Cantarutti \& A.S. Lopes. 1999. Interpretação dos resultados das análises de solos, p. 25-32. In A.C. Ribeiro, P.T.G. Guimarães \& V.H. Alvarez (eds.), Recomendações para o uso de corretivos e fertilizantes em Minas Gerais: $5^{\mathrm{a}}$ aproximação. Comissão de Fertilidade do Solo do Estado de Minas Gerais, Viçosa, MG, Brazil.

Angiosperm Phylogeny Group II. 2003. An update of the Angiosperm Phylogeny Group classification for the orders and families of flowering plants: APGII. Bot. J. Linn. Soc. 141: 399-436.

Bertoni, J.E.A. \& F.R. Martins. 1987. Composição florística de uma floresta ripária na Reserva Estadual de Porto Ferreira, SP. Acta Bot. Bras. 1: 17-26.

Braz, D.M., R.M. Carvalho Okano \& C. Kameyama. 2002. Acanthaceae da Reserva Florestal Mata do Paraíso, Viçosa, Minas Gerais. Rev. Bras. Bot. 25: 495-504.

Brown, N.1993. The implications of climate and gap microclimate for seedling growth conditions in a Bornean lowland rain Forest. J. Trop. Ecol. 9: 153-168.

Camargos, V.L. 2004. Florística e estrutura da vegetação arbórea e suas relações com a drenagem e os fatores edáficos num trecho de Floresta Estacional Semidecídua no entorno da lagoa carioca
- Parque Estadual do Rio Doce - MG. M.S. Thesis, Universidade Federal de Vicosa, Viçosa, MG, Brazil, $59 \mathrm{p}$.

Carvalho, L.M.T., M.A.L. Fontes \& A.T. Oliveira Filho. 2000. Tree species distribution in canopy gaps and mature forest in an area of cloud Forest of the Ibitipoca Range, southeastern Brazil. Plant Ecol. 149: 9-22.

Castro, P.S. 1983. Interceptação da chuva por mata natural secundária na região de Viçosa, MG. Rev. Árvore 7: 76-89.

Clark, D.B. 2002. Los factores edáficos y la distribución de las plantas, p. 192-221. In M.R. Guariguatta \& G.H. Kattan (eds.). Ecología y conservación de bosques neotropicales. LUR, San Jose, Costa Rica.

Defelipo, B.V. \& A.C. Ribeiro. 1981. Análise química do solo. Universidade Federal de Viçosa, Viçosa, MG, Brazil, 17p.

Durigan, G., G.A.D.C. Franco, M. Saito \& J.B. Baitello. 2000. Estrutura e diversidade do componente arbóreo da floresta na Estação Ecológica dos Caetetus, Gália, SP. Rev. Bras. Bot. 23: 369-381.

Ellingson, L.J., J.B. Kauffman, D.L. Cummings, R.L. Sanford \& V.J. Jamarillo. 2000. Soil N dynamics associated with deforestation, biomass burning, and pasture conversion in a Mexican tropical dry forest. For. Ecol. Manage. 137: 41-51.

Kauffman, J.B., D.L. Cummings \& D.E. Ward. 1998. Fire in the Brasilian Amazon: biomass, nutrient pools and losses in cattle pasture. Oecologia 113: 415-427.

Lieberman, M., D. Lieberman, R. Peralta \& G.S. Hartshorn. 1995. Canopy closure and the distribution of tropical forest tree species at La Selva, Costa Rica. J. Trop. Ecol. 11: 161-178.

Lorenzi, H. 1992. Árvores brasileiras: manual de identificação e cultivo de plantas arbóreas nativas do Brasil. Instituto Plantarum, Nova Odessa, SP, Brazil.

Martins, S.V. 2007. Recuperação de matas ciliares. 2a. ed. Centro de Produções Técnicas e Editora, Viçosa, MG, Brazil, 255p.

Martins, S.V., N.R.S. Silva, A.L. Souza \& J.A.A. Meira Neto. 2003. Distribuição de espécies arbóreas em um gradiente topográfico de Floresta Estacional Semidecidual em Viçosa, MG. Scie. For. 64: 172-181.

Martins, S.V. \& R.R. Rodrigues. 2002. Gap-phase regeneration in a semideciduous mesophytic Forest, southeastern Brazil. Plant Ecol. 163: 51-62. 
Martins, S.V., R. Colletti Júnior, R.R. Rodrigues \& S.Gandolfi. 2004. Colonization of gaps produced by death of bamboo clumps in a semideciduous mesophitic forest in south-eastern Brazil. Plant Ecol. 172: 121-131.

Martins, S.V. \& R.R. Rodrigues. 2005. Assessing the role of the canopy gap characteristics in the regeneration of shrub and tree species in a semideciduous mesophytic forest in South-eastern Brazil, p. 93-112. In A.R. Burk (ed.). New research on forest ecosystems. Nova Science Publishers Inc., New York, USA.

Mccune, B. \& M.J. Mefford. 1999. PC-ORD version 4.0; Multivariate analysis of ecological data; Users guide. MjM Software Design, Glaneden Beach, Oregon, USA. $47 \mathrm{p}$.

Mueller Dombois, D. \& H. Ellenberg. 1974. Aims and methods in vegetation ecology. Wiley \& Sons, New York, USA. 547 p.

Oliveira Filho, A.T. \& M.A.L. Fontes. 2000. Patterns of floristic differentiation among Atlantic Forests in Southeastern Brazil and the influence of climate. Biotropica. 32: 793-810.

Oliveira Filho, A.T. \& J.A. Ratter. 2000. Padrões florísticos das matas ciliares da região dos cerrados e a evolução das paisagens do Brasil Central durante o Quaternário tardio, p. 73-89. In R.R., Rodrigues \& H.F. LeitãoFilho (eds.). Matas ciliares: conservação e recuperação. Edusp/ Fapesp, São Paulo, SP, Brazil.

Pagano, S.N. \& H.F. Leitão Filho. 1987. Composição florística do estrato arbóreo de mata mesófila semidecídua, no município de Rio Claro (Estado de São Paulo). Rev. Bras. Bot. 10, 37-47.

Rodrigues, R.R., L.P.C. Morellato, C.A. Joly \& H.F. Leitão Filho. 1989. Estudo florístico e fitossociológico em um gradiente altitudinal de mata estacional mesófila semidecídua, na Serra do Japi, Jundiaí, SP. Rev. Bras. Bot. 12: 71-84.

Rodrigues, R.R., S.V. Martins \& M.E. Nappo. 2000. Recuperação de fragmentos florestais degradados. Ação Amb. 10: 21-23.

Salis, S.M., G.J. Shepherd \& C.A. Joly. 1995. Floristic comparison of mesophytic semideciduous forests of the interior of the state São Paulo, Southeast Brazil, Brazil. Vegetatio 119: 155-164.
Schudeller, V.V., F.R. Martins \& G.J. Shepherd. 2001. Distribution and abundance of arboreal species in the atlantic ombrophilous dense forest in Southeastern Brazil. Plant Ecol. 152: 185-199.

Shepherd, G.J. 1996. FITOPAC 1. Manual do usuário. UNICAMP, Campinas, SP, Brazil.

Silva Júnior, W.M., S.V. Martins, A.F. Silva \& P. Marco Júnior. 2004. Regeneração natural de espécies arbustivo-arbóreas em dois trechos de Floresta Estacional Semidecidual, Viçosa, MG. Scie. For. 66: 169-179.

Sos Mata Atlântica. 1998. Atlas da evolução dos remanescentes florestais e ecossistemas associados no domínio da Mata Atlântica no período 1990-1995. Fundação SOS Mata Atlântica, São Paulo, SP, Brazil.

Souza, J.S., F.D.B. Espírito Santo, M.A.L., Fontes, A.T., Oliveira Filho \& Botezelli, L. 2003. Análise das variações florísticas e estruturais da comunidade arbórea de um fragmento de Floresta Semidecídua às margens do rio Capivari, Lavras-MG. Rev. Árvore 27: 185-206.

Souza, R. \& I.F. Válio. 2003. Seedlings growth of fifteen Brazilian tropical tree species differing in successional status. Rev. Bras. Bot. 26: 35-47.

Steege, H. 1993. HEMIPHOT: a program to analyze vegetation índices, light and light quality from hemisphericl photographs. The Tropenbos Foundation, Wageningen, Netherlands. $44 \mathrm{p}$.

Ter Braak, C.J.F. 1987. The analysis of vegetation-environment relationship by canonial correspondence analysis. Vegetatio. 69: 69-77.

Ter Braak, C.J.F. 1995. Ordenation, p. 91-173. In R.H.G. Jongman, C.J.F. Ter Braak \& O.F.R. Van Tongeren (eds.). Data analysis in community and landscape ecology. Cambridge University, Cambrigde, England.

Torres, R.B., F.R. Martins \& L.S. Kinoshita. 1997. Climate, soil and tree flora relationships in forests in the state of São Paulo, southeastern Brazil. Rev. Bras. Bot. 20: 41-49.

Trichon, V., J.M.N. Walter \& Y. Laumonier. 1998. Identifying spatial patterns in the tropical rain forest structure using hemispherical photographs. Plant Ecol. 137: 227-244. 
Valverde, T. \& J. Silvertown. 1997. Canopy closure rate and Forest structure. Ecology 78: 1555-1562.

Veloso, H.P., A.L.R. Rangel Filho \& J.C.A. Lima. 1991. Classificação da vegetação brasileira, adaptada a um sistema universal. Instituto Brasileiro de Geografia e Estatística, Rio de Janeiro, RJ, Brazil.

Viana, V.M. \& A.A.J. Tabanez. 1996. Biology and conservation of forest fragments in the Brazilian
Atlantic moist forest, p. 151-167. In J. Schelhas \& R. Greenberg, (eds.). Forest patches in tropical landscapes. Island, Washington, USA.

Whitmore, T.C., N.D. Brown, M.D. Swaine, D. Kennedy, C.I. Goodwin-Bailey \& W.K. Gong. 1993. Use of hemispherical photographs in forest ecology: measurement of gap size and radiation totals in a Borneo tropical rain forest. J. Trop. Ecol. 9: 131-151. 
